\title{
Problems of cadastral recording and assessment of lands in the Sverdlovsk region of Russia
}

\author{
I. Rukavishnikova \\ Department of Environmental Economics, \\ Ural Federal University, Russia
}

\begin{abstract}
The creation of a reliable system of land registration and valuation is a necessary condition for the further development of the real estate market in Russia. The purpose of this study is to analyse the currently existing problems in state cadastral registration and land valuation in the Russian Federation, both at the Federal and regional levels. In the present paper, information on the results of the cadastral valuation of land parcels in the Sverdlovsk region is presented. Based on an analysis of the data, it is possible to distinguish the following problems in this area: the imperfection of the methods of valuation and regulatory framework, the lack of accurate land boundaries: secrecy and opacity in the system of assigning information. The main stages of professional cadastral registration in the Russian Federation are reviewed. The approaches taken to determine the cadastral value of land according to Russian practices are discussed. It is shown that the cadastral value established can vary by several times according to the different valuation techniques employed. The possibility of challenging the results of an erroneous determination of cadastral value is demonstrated based on an analysis of legal precedents established in the Urals region. A conclusion is reached about the need to improve the methodological and legislative frameworks of cadastral valuation of land parcels as real estate. A number of possible paths forward are proposed and specific activities that should contribute to an improvement of the quality of land relations are outlined. It is proposed that regional experiences of cadastral assessment of lands can be used to support reform at the Federal level.

Keywords: cadastral recording, valuation of land parcels, cadastral value, assessment methods, State Real Estate Cadastre, land relations.
\end{abstract}




\section{Introduction}

One of the main directions of the present stage of Russian economic development is to create a management system for the country's territories and to ensure its effective functioning. A prerequisite for sustainable development of the territory in a developing market economy is the provision of government guarantees supporting property ownership rights, including land. To solve this problem it is necessary to create a reliable system of recording and valuation of real estate - in the first instance, land.

\section{The formation of professional cadastral registration in Russia}

The formation of the professional cadastral recording and land valuation in Russia has been a relatively recent phenomenon in historical terms. At the beginning of the 20th century, Russian jurists considered using the Torrens system [1] for land registration. However, following the October Revolution in 1917, land was nationalised, i.e. declared to be national property. As a consequence, for several decades, land was actually public property and, as such, was not subject to taxation. Nevertheless, under the conditions of the planned economy, a need existed for a wide variety of information about land. In the Soviet Union, a system for regular land surveys was formed and successfully operated [2]. In accordance with the Decree of the USSR Council of Ministers, the registration of land users was conducted from 1955 onwards; the Land Cadastre of the USSR was formed on the basis of a summarisation of this data. The Land Cadastre of the Soviet period, approved in 1968, is a set of tables of data on land quality characteristics, differentiated by users. The Cadastre was provided with detailed information on agricultural lands and forest resources. However, information about land-based industry and populated areas was reproduced in simplified form and lacked objectivity [3].

In the 1990s, land relations in Russia - for that matter, the economic system as a whole - underwent significant changes. Land once again became the object of commercial exchange and subject to taxation. The period from 1991 to 2000 was characterised by high volatility. The disposal (transfer of ownership) of land was carried out at the behest of landowners without normative enactment by regulatory authorities. This resulted in a lack of fiscal information and an inability to properly identify and collect payments of land tax. Often there were boundary disputes, which could not be resolved in a civilised manner due to the lack of land registry information concerning land boundaries. It became necessary to modify and update the land legislation.

In 2000, a new law “On State Land Cadastre" was enacted. In accordance with this law, the Land Cadastre was defined as "a systematic set of documented information obtained as a result of state cadastral registration of land, concerning the location, purpose and legal status of the land of the Russian Federation".

It is worth noting that until 2008, the land cadastre is often regarded as one of the state cadastres of natural resources, amongst which are also included the forest 
cadastre, water cadastre, mineral resources cadastre and wildlife cadastre. This approach can be considered as a legacy of the Soviet period when land, along with other natural resources, was considered to be public property. With the adoption of the 2007 Federal Law “On State Real Estate Cadastre", separate land, forest and water cadastres effectively ceased to exist. The functions of forest and water cadastres were partially fulfilled by the forest and water registries and partly moved to the State Real Estate Cadastre (SREC). All land cadastre functions were moved to the SREC.

Currently, the functions of organising a unified system of state cadastral registration of real estate and state registration of rights to immovable property and transactions thereof are assigned to the Federal Service for State Registration, Cadastre and Cartography (Rosreestr) [2]. The service is a division of the Ministry of Economic Development of the Russian Federation. State cadastral valuation of real estate, until recently, was one of the functions of Rosreestr; however, from 1st January 2013, it lost the corresponding authority. Now only the executive authority of the Russian Federation or the local authority may act for the customer of the work. Accordingly, funding for such work is made available from the regional or local budgets.

The outcome of the assessment consists in the cadastral value, which is taken into account at privatization of state or municipal property, and also serves as a basis for calculating land tax and determining rents paid for the possession and use of land, whether ownership is located at the state or municipal level. From 2014, the cadastral value of SREC entities in several regions of the Russian Federation started to be used as the basis for calculating property tax, replacing the property tax and land tax. There are plans to extend this experience to all subjects of the Federation. These facts impose high demands on the accuracy of determining the cadastral value of real estate property, including land.

\section{The approaches for determining the cadastral value of parcels of land}

Currently by cadastral value is understood market value of the real estate as determined by mass appraisal, or, if it is impossible to determine the market value using mass appraisal methods, the market value is determined individually for each property in accordance with the legislation concerning appraisal activity. By the mass appraisal of real property is understood the process of determining the value when grouping objects of evaluation with similar characteristics, in which mathematical modelling and other valuation techniques are used depending on the specific evaluation approaches taken [3]. However, some individual characteristics of properties included in the grouping cannot be ignored. Therefore, the value calculated by applying methods of mass appraisal, has a sufficiently high accuracy. In contrast, the market value determined individually for each concrete property takes into account all the possible factors that have an impact on the final value. Nevertheless, given the scale of the subjects of the Russian Federation, it is advisable to use mass appraisal methods of real estate evaluation, since this 
method for determining cadastral valuations is considered to be less costly for the state.

\section{Cadastral land valuation in the Sverdlovsk region}

Information on the amounts and years of state cadastral valuation of different categories of land Sverdlovsk region is given in table 1 .

Table 1: State cadastral valuation of land of different categories in the Sverdlovsk region (according to [4]).

\begin{tabular}{|c|c|}
\hline Land category & $\begin{array}{c}\text { Year of State cadastral } \\
\text { valuation of land }\end{array}$ \\
\hline \multirow{3}{*}{ Agricultural land } & $2000-$ Round 1 \\
\hline & 2006 - Round 2 \\
\hline & 2011 - Round 3 \\
\hline \multirow{3}{*}{$\begin{array}{l}\text { Parcels of land for cottage building, } \\
\text { gardening, included as part of agricultural } \\
\text { land }\end{array}$} & 2003 - Round 1 \\
\hline & 2008 - Round 2 \\
\hline & $2011-$ Round 3 \\
\hline \multirow{4}{*}{ Land settlements } & 2002 - Round 1 \\
\hline & 2007 - Round 2 \\
\hline & $2010-$ Round 3 \\
\hline & $2012-$ Round 4 \\
\hline \multirow{3}{*}{ Industrial land and other special purposes } & 2003 - Round 1 \\
\hline & 2008 - Round 2 \\
\hline & $2012-$ Round 3 \\
\hline \multirow{2}{*}{$\begin{array}{l}\text { Land of specially protected territories and } \\
\text { objects }\end{array}$} & 2003 - Round 1 \\
\hline & $2009-$ Round 2 \\
\hline Water resources & $2010-$ Round 1 \\
\hline \multirow{2}{*}{ Forest resources } & 2003 - Round 1 \\
\hline & 2008 - Round 2 \\
\hline
\end{tabular}

Most often carried out by State cadastral land valuation (SCLV) in populated areas, primarily due to the frequent contestation of the value of parcels of land in this category.

The main reasons for such a state of affairs can be considered:

- stable market demand for land in this category,

- a significant change in the methodological framework used in different rounds of evaluation,

- imperfection and limited experience in applying the new assessment methodology. 
The first round of SCLV in populated areas (2002) was carried out in accordance with the Methods of State Cadastral Valuation of Land Settlements (hereinafter - Methods); the second round (2007) was conducted in accordance with the Methodological Guidelines for State Cadastral Valuation of Land Settlements (hereinafter referred to as Guidelines). In this case, the procedure for determining the cadastral value of the land contained in the Methods varies considerably from that given in the Guidelines, namely [3]:

1. The Guidelines provide for the calculation of the cadastral value for the individual land parcel, while the Methods establishes a specific index of the cadastral value of land for each of the groups of types of functional use of land.

2. In place of the 14 types of functional land use given in the Methods, the Guidelines introduced 16 types of permitted uses of land. This change had a significant impact on the cadastral valuation of individual plots. For example, parcels of land intended to accommodate homes for individual residential development began to be referred to in the Guidelines as subsidiary smallholdings, whereas in the Methods they were referred to as land parcels for of agricultural use. This change caused a sharp rise in the price of land in populated rural settlement areas.

3. According to the Methods, the cadastral value of the land parcel should reflect the values of its most recent actual usage. According to the Guidelines, the value of land is determined by the principle of highest and best use; in this case, the criterion of the permitted usage of the parcel that maximises its value is selected.

In some cases, the approach taken in the Guidelines seems to us unnecessary, since it can sometimes lead to a situation in which the values of adjacent sections differ considerably, resulting in the owner of a parcel having a higher estimated value having to pay exorbitant taxes.

The use of the new methodological framework for the assessment in the second round, as well as a significant number of errors committed by cadastral engineers, has led to a substantial increase in land valuations and accordingly higher taxes. This has caused resentment in the general population and representatives of small and medium-sized businesses.

Calculated according to the results of SCLV 2007-2008, land tax in the Sverdlovsk region was the highest in the Russian Federation, with tax revenues exceeding levels five times that of other regions. This created the need for a third round of SCLV in settlements in 2010-2011. At the end of the third round of the cadastral valuation, certain types of land settlement valuation were significantly altered compared to the valuations resulting from the previous estimate (table. 2).

\section{Challenging the state cadastral value of land parcels}

The unreasonably high cadastral value of land has led to a saturation of cases appealing specific valuations in the court of arbitration. According to the Council of Municipalities of the Sverdlovsk region [5], in 2012, the Arbitration Court of the Sverdlovsk region received about 500 complaints, of which $98 \%$ were satisfied. 
Table 2: Change (+ increase; - decrease) in the value of land after the third round of valuation of land in populated areas [5].

\begin{tabular}{|l|c|}
\hline Parcels of land & $\begin{array}{c}\text { Changes in the cadastral } \\
\text { valuation, } \%\end{array}$ \\
\hline under multi-storey buildings & -28 \\
\hline under low-rise and individual buildings & -6 \\
\hline under office buildings & -21 \\
\hline under shopping centres & +9 \\
\hline under garages and parking lots & +31 \\
\hline $\begin{array}{l}\text { used: } \\
\text { for the development of mineral deposits; } \\
\text { for the construction of roads }\end{array}$ & +72 \\
\hline
\end{tabular}

We will consider a few illustrative examples of court decisions relating to the reduction of cadastral value to the benefit of entrepreneurs. Examples of changes in cadastral value by the decision of the arbitration court of the Sverdlovsk Region are shown in table 3 .

Table 3: Change (+ increase; - decrease) in the value of land after the third round of valuation of land in populated areas [6].

\begin{tabular}{|l|c|c|}
\hline $\begin{array}{l}\text { Enterprise - the plaintiff (the } \\
\text { owner of the land) }\end{array}$ & $\begin{array}{c}\text { Contested } \\
\text { cadastral value of } \\
\text { the land, mln } \\
\text { RUB. }\end{array}$ & $\begin{array}{c}\text { Cadastral value } \\
\text { determined by the } \\
\text { arbitral tribunal, } \\
\text { mln RUB }\end{array}$ \\
\hline Concern "Kalina" & 86.23 & 21.6 \\
\hline Sports complex "Uktus" & 423 & 110 \\
\hline $\begin{array}{l}\text { Shopping and entertainment } \\
\text { complex "Greenwich" }\end{array}$ & 414 & 173 \\
\hline
\end{tabular}

It can thus be seen that lawsuits contesting the cadastral value of land generally have satisfactory outcomes. However, it should be noted that the practice of returning overpaid land tax from the budget is not currently well established. This is due to an ambiguity in the interpretation of the regulations. It is evident that the laws governing cadastral valuation, as well as the methods used in the valuation of land settlements, are capable of further improved.

\section{Other problems and challenges of cadastral recording and land valuation}

Among the urgent problems manifested in cadastral registration, including in the Sverdlovsk region, should be included the problem of lack of precise land parcel boundaries. 
Is important to note that from 1st January 2018, a ban comes into force (with no exceptions) on the disposal of land in respect of which there is no information about the location of boundaries [7]. This is reflected in the action plan "Improving the Quality of Public Services in the Field of State Cadastral Recording of Real Estate and State Registration of Rights to Immovable Property and Transactions Pertaining Thereto" ("roadmap").

According to the data of the Federal Ministry of Economic Development, the funding of cadastral works to identify the exact boundaries of land will be made at the expense of regional and municipal budgets, as well as by grants from the Federal budget. The amount of funds for these works will be about 119 billion rubles.

Of no less importance is the need to find a solution to the problem of secrecy and lack of transparency within the system used to provide information about unused and already used lands. The presence of a significant number of administrative barriers in the sphere of land relations is a primary cause of corruption, based on which, for example, fraud associated with the illegal transfer of land from one category to another tends to proliferate. It should be noted that overcoming this problem is also related to the implementation of the action plan "roadmap", which is based on the concept of the Federal target programme "Development of a Unified State System of Registration of Rights and Cadastre of Real Estate in the Years 2014-2019" (FTP), total funding of which will be 62,778 billion rubles, including 60,416 billion rubles from the Federal budget and 2,362 billion rubles from the budgets of the Subjects of the Russian Federation.

One of the most important results of the projected implementation of the "roadmap" and the Federal programme is the creation by 2018 the Unified State Register of Real Estate (EGRON) based on the combination of information from two sources: State Real Estate Cadastre and the Unified State Register of Rights to Immovable Property and Transactions Pertaining Thereto. The establishment of such a unified state information resource is highly desirable, as it would facilitate timely and rapid collection of data on real property, as well as reducing transaction risks in the property market.

\section{Conclusion}

The main problems in the sphere of state cadastral and land evaluation include the inadequacy of present valuation techniques and legislation; the lack of accurate land boundaries; and secrecy and opacity within the information system. Despite the existence of these problems, there is ongoing development within the institution of cadastral recording and valuation of lands. Improving the methodological and legislative frameworks of cadastral valuation will improve the quality of relations in the sphere of the real estate market of the country. In this case, it may be useful to refer to the experience of individual regions in the implementation of reforms at the Federal level. 


\section{References}

[1] Pokrovsky, I. A., Basic Problems of Civil Law, Petrograd: "Pravo", 1917. Classics of Russian Law, Project of the company "Consultant Plus", http://civil.consultant.ru/elib/books/23/page_23.html.

[2] Federal Service for State Registration, Cadastre and Cartography (Rosreestr), https://rosreestr.ru.

[3] Magaril, E.R., Berezyuk, M.V., Rukavishnikova, I.V., Environmental Economics: A Multidisciplinary Approach, Textbook, Publishing House "KDU”: Moskow, 2013.

[4] Report on the Status and Use of Land in the Sverdlovsk Region in 2012, Website of the Federal Service for State Registration, Cadastre and Cartography in the Sverdlovsk region, www.to66.rosreestr.ru.

[5] The official website of the Council of Municipalities of the Sverdlovsk Region, http://smo.midural.ru.

[6] Rukavishnikova, I.V., Peshkova A.A., The Problems of cadastral registration and lands' estimation in Sverdlovsk region. Discussion, 4(45), pp. 98-105, 2014.

[7] Directive of the Government of the Russian Federation on June 28, 2013. 